\title{
BRATI PLINIJA: O PLINIJU STAREJŠEM, LIKOVNI UMETNOSTI IN METODI
}

Ključne besede: Plinij starejši, Naravoslovje, interpretacija virov, antična umetnost

Sodobnemu bralcu se Plinijeva "poglavja o umetnosti lahko zdijo presenetljivo domača. S svojim seznamom umetnikov in del, ki so urejena kot niz slogovnih iznajdb in izboljšav, Plinijev opis grške umetnosti ... v marsikaterem pogledu ustreza zdaj splošno uveljavljenemu modelu zgodovine umetnosti. Vzrok za to je seveda $v$ dejstvu, da je Plinijevo besedilo igralo osrednjo vlogo pri razvoju tega modela (Carey, 2003, 13).

I.

Leta 1863 se je angleški slikar nizozemskega rodu Sir Lawrence AlmaTadema prvič poročil. Na poročnem potovanju po Italiji sta se z ženo za dalj časa ustavila v Firencah, Rimu in Neaplju, kjer sta občudovala ostaline preteklih časov. Verjetno zaradi splošnega navdušenja, ki ga je bilo v tistem času deležno pisanje italijanskega arheologa, Giuseppeja Fiorellija, vodje izkopavanja v Pompejih, sta se tudi onadva odločila za obisk ruševin "pokopanega mesta pod Vezuvom. Obisk arheološkega najdišča je v AlmaTademi vzbudil zanimanje za antiko, ki je močno zaznamovalo njegovo nadaljnjo poklicno pot - prav slike $\mathrm{z}$ antičnimi motivi, ki jih je v naslednjih letih slikal tudi na podlagi fotografij, posnetih v Pompejih, so mu namreč prinesle tako želeno priznanje in slavo.

Pet let po vrnitvi s poročnega potovanja je Alma-Tadema izdelal sliko Fidija in Partenonski friz (slik. 1). Na njej vidimo kiparja Fidijo, ki vodi svoje goste pri ogledu pravkar dokončanega friza osrednjega atenskega sve- 
tišča, posvečenega boginji Ateni Partenos. Fidija in obiskovalci, med njimi so domnevno tudi Perikles s svojo priležnico Aspazijo in filozof Sokrat s prijateljem Alkibiadom (Spivey, 1996, 152), hodijo po zidarskem odru, kar jim omogoča, da si kiparski okras tik pod streho svetišča ogledujejo tako rekoč v višini oči - privilegij, ki naj pozneje ne bi bil namenjen nikomur več. Pred frizom stoji Fidija z zvitkom v roki, očitno pripravljen na morebitna vprašanja svojih obiskovalcev.

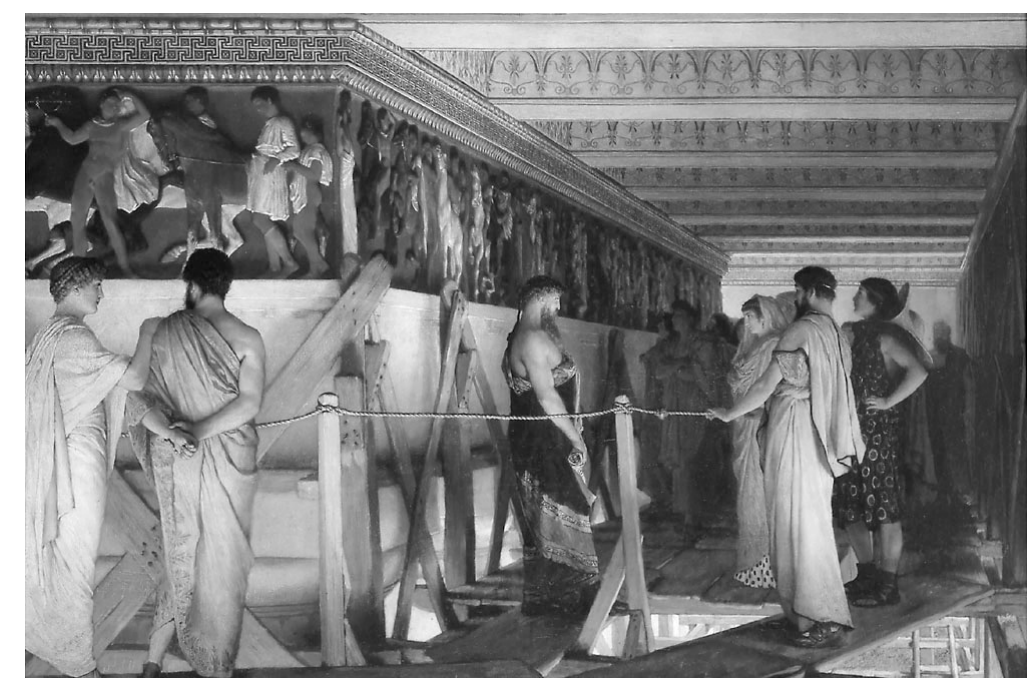

slik.1: Lawrence Alma-Tadema, Fidija in Partenonski friz, 1868, Birmingham Museums and Art Gallery, Birmingham vir: http://commons.wikimedia.org/wiki/Image:1868

Z izločitvijo Fidije iz skupine drugih figur, $\mathrm{z}$ njegovo premišljeno umestitvijo pred sam friz, ki mu sicer kaže hrbet, in s skrbnim oblikovanjem njegove figure - pomembna podrobnost je tudi že omenjeni zvitek, najverjetneje gre za načrt partenonskega kiparskega okrasa -, je Alma-Tademi uspelo jasno ponazoriti podobo, ki si jo je njegovo stoletje oblikovalo o mojstrih klasične umetnosti na splošno, še posebej pa o Fidiji. ${ }^{1}$ Na njegovi sliki se nam Fidija

1 Veliko Britanijo je potem, ko je Lord Elgin v London pripeljal dele partenonskega kiparskega okrasa, zajela prava evforija za Fidijo. V reviji Gentleman's Magazine so npr. januarja 1818 objavili naslednje verze, posvečene velikemu kiparju: 
predstavlja kot Umetnik, navdahnjeni posameznik, ki s svojimi nesmrtnimi deli - plodom svojega prirojenega talenta - služi vsemu človeštvu.

Tako razumljen je Fidija postal sestavni del umetnostnozgodovinskega Kanona. To najlepše kažejo pregledi grške umetnosti, v katerih poglavja o klasični umetnosti brez omembe Fidije in njegovih del pravzaprav ne more biti. Tudi Jerome J. Pollitt, ki zgodovino antične grške umetnosti obravnava na podlagi ohranjenih pisnih virov, začenja svoje poglavje o kiparstvu visokega klasičnega obdobja s Fidijo (Pollitt, 1990, 53 ss.). Mojstra obravnava v skladu z vsemi umetnostnozgodovinskimi pravili. Na začetku predstavi Fidijevo življenje, kot se nam kaže iz ohranjenih pisnih virov, in nadaljuje z opisi njegovih del. Najprej se ustavi pri Fidijevih najpomembnejših delih, Ateni Partenos (slik. 2), Olimpijskemu Zevsu (slik. 3) in še nekaterih pomembnejših kipih, nato pa konča poglavje o Fidiji z opisom njegovih manj znanih del.

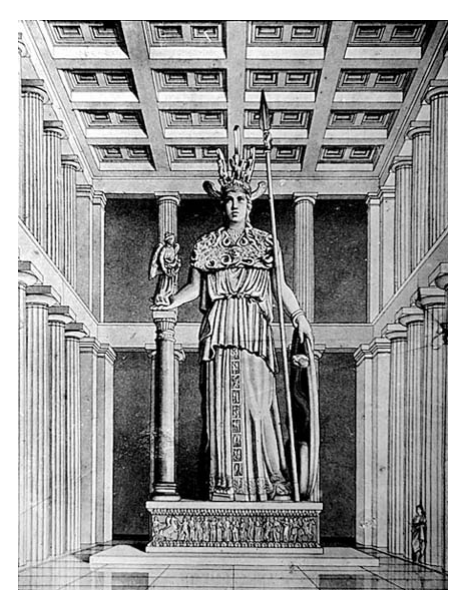

slik. 2: Rekonstrukcija Atene Partenos

vir: http://ccwf.cc.utexas.edu/ perlman/myth/lecture14.html

Phidias! thou hast immortalized thy name In these thy handy-works, and they will tell Loud as ten thousand thunderings thy fame Wherever truth and beauty deign to dwell.

Avtor verzov je domnevno prijatelj pesnika Johna Keatsa Benjamin Haydon. Navdušenje nad Fidijevim mojstrstvom pa ni zajelo samo laične javnosti, pač pa tudi profesionalne kritike. Tako je npr. še leta 1871 John Ruskin z zanosom govoril o "plemeniti Fidijevi roki« (Spivey, 1996, 152-153). 
Z Alma-Tademovo sliko in Pollittovo analizo pisnih virov si lahko ustvarimo precej podrobno podobo mojstra Fidije, katerega ustvarjalni genij je botroval nastanku ne samo nadnaravno velikih hrizelefantinskih kipov Atene Partenos in Olimpijskega Zevsa ter množice manjših, predvsem Ateninih kipov, marveč tudi klesarske opreme Partenonskega friza, katerega izdelavo naj bi nadzoroval. S svojim delom naj bi Fidija jasno naznanil novo kvaliteto v grškem kiparstvu, s čimer je utrl pot ustvarjalnim težnjam, ki so grški umetnosti zagotovile odličnost in neponovljivost, Fidiji samemu pa prinesla sloves enega največjih grških umetnikov.

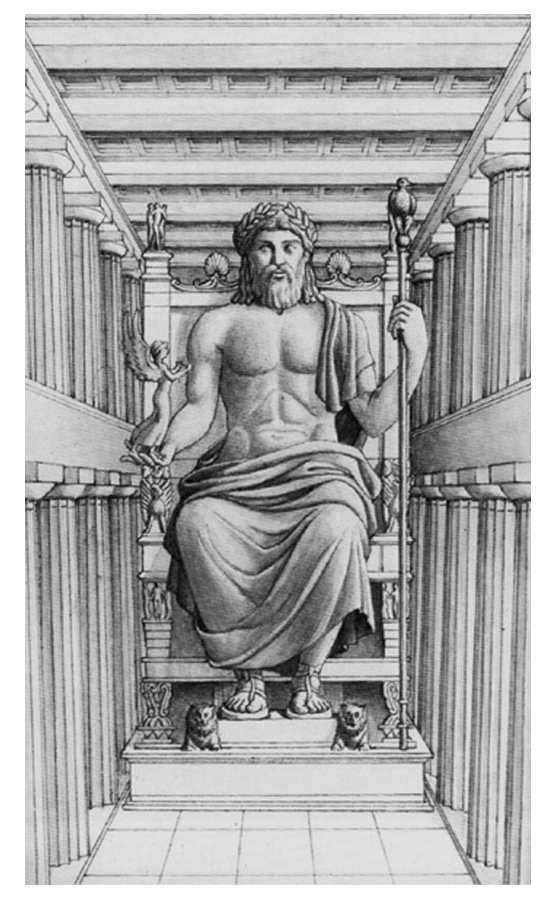

slik. 3: Rekonstrukcija Olimpijskega Zevsa vir: http://www.odisseyadventures.ca/articles/olympia/figure9_zeustemple_interior.htm

Vprašanje, ki se postavi, je, kako dobro, če sploh, se ta podoba ujema s pravim človekom, ki je živel pred slabim pol tretjim tisočletjem in ki ga zdaj poznamo pod imenom Fidija. Podoba Fidije kot Umetnika temelji namreč na umetnostnozgodovinskih konceptih, ki so se dokončno izoblikovali prav v času, ko je Alma-Tadema slikal svoje videnje nastanka Partenonske- 
ga friza. Koncepti umetnosti, umetnika in umetniškega ustvarjanja pa tudi kronološki model, ki temelji na ideji slogovnega razvoja, so rezultat točno določenega časa, zaradi česar njihova uporaba kliče po precejšnji previdnosti.

Vsakič, ko razmišljamo o grški umetnosti, se moramo vprašati, kako so Grki sami razumeli ne samo artefakte, ki so predmet našega preučevanja, temveč tudi samo dejavnost, katere rezultat so. Kakšnemu namenu so služili npr. grški kipi in ali so se ti nameni s časom spreminjali? Kako so Grki gledali na posameznike oz. skupine, ki so kipe izdelovali, in kako so dojemali (vrednotili) njihovo dejavnost? So razmišljali o ustvarjalnosti kiparjev podobno kot mi? Da bi našli odgovore na tovrstna vprašanja, se raziskovalci ponavadi zatekamo $k$ preučevanju pisnih virov. Zaradi najrazličnejših dogodkov v preteklosti so namreč artefakti, ohranjeni v svojem izvirnem okviru, izredno redki, pa še tisti maloštevilni ohranjeni po mnenju številnih raziskovalcev na nekatera vprašanja ne odgovarjajo.

Vsako branje zgodovinskega vira, pa naj gre za pisni ali materialni vir, ki naj bi raziskovalcu omogočilo rekonstrukcijo preteklosti, zahteva njegovo posebno pozornost, predvsem pa nenehno samorefleksijo. Še toliko bolj to velja pri interpretaciji preteklosti, ki temelji na kombiniranju različnih vrst virov. Raziskovalec se mora gibati v presečnem polju med artefaktom, pisnim virom, ki je povezan $\mathrm{z}$ njim, ter prvotno in sedanjo recepcijo obeh, tako artefakta kot tudi pisnega vira. Povrh vsega pa ne sme pozabiti še na dejstvo, da je tudi pisni vir, ne glede na to, kako časovno blizu si je s preučevanim artefaktom, le njegova interpretacija.

Eno najpomembnejših antičnih besedil, ki je vplivalo ne samo na poznejše razumevanje grške umetnosti, ampak tudi na oblikovanje stoletja mlajših umetnostnozgodovinskih konceptov, modelov in metod, je Naravoslovje, obširno delo organizirano v sedemintridesetih knjigah, rimskega pravnika, zgodovinarja in naravoslovca Gaja Plinija Sekunda (slik. 4). Enciklopedično naravoslovna zasnova dela je narekovala umestitev in tudi način, na katerega se je Plinij lotil opisovanja izvora in razvoja nekaterih zvrsti likovne umetnosti. O likovni umetnosti namreč ni razpravljal kot o celoti, kakor bi pričakovali od sodobnega umetnostnega zgodovinarja, temveč je obravnavo posameznih zvrsti v svoje delo uvrstil glede na zanje značilne materiale. Tako na primer $\mathrm{v} 34$. knjigi, $v$ kateri se ukvarja $\mathrm{z}$ neple- 
menitimi kovinami, obravnava kiparstvo v bronu (Naravoslovje, 34, 9-19), v 35. knjigi, kjer teče beseda o zemlji, opisuje slikarstvo (Naravoslovje, 35, 1-45), v 36. knjigo, ki je posvečena kamninam, pa je umestil oris razvoja kiparstva v kamnu (Naravoslovje, 36, 4) in krajši opis posameznih arhitekturnih tipov iz Egipta in Rima (Naravoslovje, 36, 14-24). ${ }^{2}$

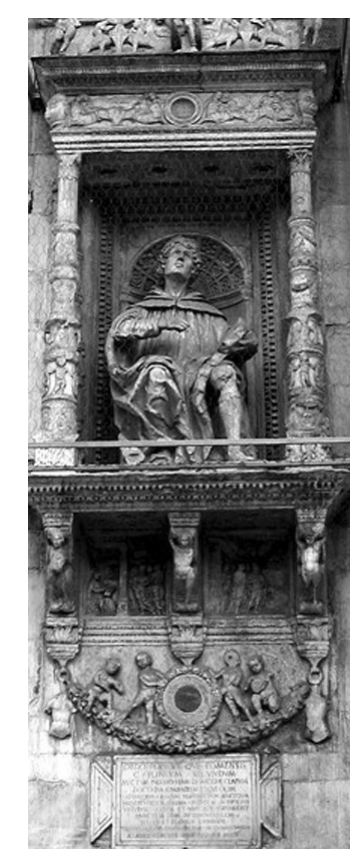

slik. 4: Tommaso in Giacomo Rodari, Plinij starejši, ok. 1485, fasada stolnice, Como

vir: http://www.chieracostui.com/costui/images/foto/coplinio2.jpg

Plinij se pri opisovanju razvoja posameznih zvrsti likovne umetnosti pogosto sklicuje na druge pisce. Že v uvodni knjigi, ki jo je namenil orisu vsebine sledečih 36 knjig, ob kratkem opisu vsebine posamezne knjige bralca

2 Navedene knjige sicer niso edina mesta, kjer se Plinij ukvarja z likovno umetnostjo, saj lahko sledimo omembam posameznih spomenikov tako rekoč skozi vseh $37 \mathrm{knjig}$. Čeprav te posamezne omembe bralcu ne dajejo zaključenega pogleda na likovno umetnost, pa niso prav nič manj pomembne za razumevanje Plinijevega odnosa do likovne ustvarjalnosti. Sorcha Carey celo opozarja, da so prav te omembe bistvenega pomena za razumevanje Plinijevih literarnih prijemov, s katerimi je zgradil svojo pripoved (Carey, 2003, 42 ss.). 
posebej opozarja na avtorje, pri katerih je črpal (Naravoslovje, 1). Tudi pri opisovanju posameznih likovnih zvrsti v 34., 35. in 36. knjigi na več mestih opozarja, da je kakšen podatek o umetniku ali njegovem delu povzel po kakšnem starejšem avtorju, torej da opisuje nekaj, česar sam sploh ni videl. Avtorje, na katere se opira, včasih imenuje, ${ }^{3}$ pogosto pa mu zadostuje, da se sklicuje zgolj na domnevne poznavalce umetnosti. ${ }^{4}$ Plinij večkrat omenja tudi avtorje, katerih dela v njegovem času niso bila več ohranjena in jih je pred pozabo obvaroval samo spomin na njihovo nekdanjo slavo. Kljub temu jih $\mathrm{z}$ natančnostjo vestnega enciklopedista uvrsti v svojo pripoved, da bi obdržal celovitost svojega pregleda. ${ }^{5}$

Plinijev opis razvoja in dosežkov različnih zvrsti likovne umetnosti se današnjemu bralcu kaže prvenstveno kot obširen seznam del posameznih bolj ali manj slavnih klesarjev, modelarjev in slikarjev. Od časa renesanse dalje so zato odlomki Plinijevega Naravoslovja glavno referenčno besedilo pri preučevanju grškega kiparstva in slikarstva. Raziskovalci ga uporabljajo kot pomoč pri vzpostavljanju splošne razvojne črte obeh likovnih zvrsti pa tudi pri atribuciji artefaktov posameznim avtorjem (Isager, 1998, 13). Prav dejstvo, da so odlomki Plinijevega Naravoslovja, zlasti tisti, v katerih opisuje slikarstvo in kiparstvo, dobili status referenčnega besedila pri preučevanju grške umetnosti, je pripeljalo do tega, da jih stroka že od nekdaj bere presenetljivo enoznačno. Umetnostni zgodovinarji, arheologi in vsi drugi raziskovalci antične umetnosti, ki se pri svojih interpretacijah sklicujejo na Plinija, so si bolj ali manj edini, o čem je pisal oz. kakšne informacije bi se dalo potegniti iz njegovega besedila. ${ }^{6}$ In kaj naj bi po ustaljenem prepričanju lahko v Naravoslovju izvedeli o grški umetnosti?

3 Kot vire pri opisovanju zgodovine slikarstva Plinij omenja mdr. Aristotela in Teofrasta ( $\mathrm{Na}$ ravoslovje, 7, 56) pa Antigona in Ksenokrata (Naravoslovje, 35, 36). Slednjega poleg Marka Varona (Naravoslovje, 34, 19), Durisa s Samosa (Naravoslovje, 34, 19) idr. navaja kot vir tudi pri opisu razvoja kiparstva (Naravoslovje, 34, 19).

4 Tako npr. na nekem mestu uporabi izraz peritiores artis $(35,36)$.

5 Marsikateri podatek, ki ga navaja Plinij, je zato po mnenju večine raziskovalcev nezanesljiv ali vsaj nepreverjen (Williams, 2004, 10).

6 Po mnenju Jacoba Isagerja so bili zaradi tovrstnega, »referenčnega « načina branja Plinijevih odlomkov o likovni umetnosti raziskovalci pogosto razočarani, ko npr. besedilo ni ponudilo "pravih odgovorov« na nekatera vprašanja ali pa ko se Plinijeve navedbe niso skladale $\mathrm{z}$ novoodkritimi kipi in poslikavami (Isager, 1998, 13). 
II.

Zgodovino slikarstva in kiparstva Plinij opredeli z naštevanjem posameznih avtorjev, ki so na takšen ali drugačen način prispevali k razvoju slikarske in klesarske tehnike oz. veščine modeliranja, in navajanjem njihovih del. V 35. knjigi, kjer se Plinij ukvarja s slikarstvom, bralcu na kratko opiše domnevne začetke te likovne zvrsti. Začetke slikarstva naj bi bilo po njegovih podatkih treba iskati bodisi pri Egipčanih bodisi pri Grkih. Začetno stopnjo slikarske veščine je domnevno pomenilo preprosto obrisovanje človeške sence, malo pozneje pa se je pojavila tudi že nekoliko bolj izdelana tehnika upodabljanja - risanje. Slikarji so po Plinijevih navedbah sprva uporabljali samo eno barvo: figure so oblikovali $\mathrm{z}$ močno obrisno črto, njihovo notranjost pa so puščali prazno. Šele pozneje so menda začeli notranjost figur zapolnjevati z različnimi barvnimi pigmenti (Naravoslovje, $35,5)$.

Plinijev opis razvoja slikarstva temelji na zasledovanju postopnega napredka slikarske tehnike od preprostih začetkov, obdobja njenega vrhunca do časov počasnega zamiranja. Kot pojasni že v uvodu svojega opisa, je slikarstvo veščina, katere dnevi slave so že minili (Naravoslovje, 35, 1). Napredovanje slikarske veščine Plinij vidi v uvajanju različnih tehničnih novosti. Slikarji, ki so jih uvajali, so omogočili, da se je njihova veščina skozi zaporedne stopnje počasi izboljševala, dokler ni končno izgubila zagona. Njegovo občudovanje tehničnih novosti je bilo zelo veliko. Tako še pri avtorjih, delujočih po času največjih mojstrov, $\mathrm{z}$ navdušenjem omenja nekatere izboljšave, ki so jih uvedli. ${ }^{7}$ Enako velja tudi za kiparstvo. Tudi razvoj te likovne zvrsti - velja tako za oblikovanje v kovini kot tudi za obdelovanje kamna - je namreč Plinij razlagal kot postopno nadgrajevanje in izboljševanje (Naravoslovje, 34, 17 in 34, 19).

V svojem pregledu avtorjev Plinij poleg najbolj slavnih del pogosto omenja tudi pomembne dogodke iz njihovega življenja. Vendar pa bralec že pri površnem branju ugotovi, da so Plinijevi opisi življenj umetnikov bolj kot njihovi pravi življenjepisi anekdotična zbirka klišejskih prigod (Williams, 2004, 15-16; Schneider Adams, 1996, 104 ss.). Te niso same sebi namen,

7 To velja npr. za rimske slikarje, ki so živeli v času, ko je slikarstvo po Plinijevem mnenju v splošnem že nazadovalo (Naravoslovje, 35,6 in 7). 
temveč je pisec prav z njimi podkrepil zamisel o postopnem napredovanju posamezne likovne zvrsti. Ideja, ki namreč napaja vse opisane dogodke, je jasna - vsak umetnik je presegel svoje predhodnike v veščini pa tudi v bogastvu in slavi. To naj bi mu omogočile njegova ustvarjalnost, inventivnost in samozavest, ki naj bi mejila že na domišljavost.

Klišejskost opisov življenjepisov pomembnih umetnikov dobro razberemo v Plinijevih opisih življenja posameznih grških slikarjev (Naravoslovje, 35, 36). Ena od pomembnih podrobnosti iz slikarjevega življenja, ki se vedno znova ponavlja, je podatek, pri kom se je učil oz. koga je v svoji veščini presegel. V 35. knjigi lahko med drugim preberemo, da je Zevksis premagal svoje učitelje, čeprav avtor ne ve natančno, kdo so ti bili. Zevksisa je pozneje v veščini premagal njegov učenec Parazij, tega pa je presegel Timant. Prav na ta način vzpostavljeni »rodopis $\aleph^{8}$ slikarjev, ki temelji na »dejstvu«, da učenec vedno preseže svojega učitelja, je Pliniju omogočil, da je slikarstvo obravnaval kot počasi napredujočo veščino.

Prevlado nad tekmeci je umetniku zagotovilo njegovo znanje in obvladovanje veščine. Znanje, ki je bilo pomembno za umetnika, pa ni bilo vezano le na likovno področje. Plinij bralca posebej opozori na dejstvo, da je bil grški slikar Pamfil prvi slikar, ki je bil visoko izobražen »na vseh področjih znanja «. Avtor izrecno poudarja, da zlasti brez poznavanja aritmetike in geometrije Pamfilova umetnost ne bi mogla doseči popolnosti. ${ }^{9}$ Pamfil je bil

8 Glede na to, da je Plinij s svojim opisom razvoja slikarstva in kiparstva postavil vzor, ki so ga posnemali pisci še dolga stoletja, ni presenetljivo, da je koncept "oče-sin « pomembno zaznamoval umetnostno zgodovino. Bolj presenetljiva je ugotovitev - kot opozarjajo zlasti feministično usmerjeni raziskovalci -, da koncept pomembno zaznamuje disciplino tudi še $\mathrm{v}$ času, ko je presegla zgolj biografsko obravnavo zgodovine likovne umetnosti. Razlog za to David Summers vidi v samem konceptu oblike, ki naj bi bila že od antičnih časov, odločilno zaznamovana s spolom (gender) (Summers, 1994, 384-411).

9 Zakaj Plinij med splošnim znanjem izrecno omenja prav obvladanje aritmetike in geometrije, je razumljivo. Obe sta pomembni za pravilno upodabljanje človeških proporcev. Upoštevanje številčnih razmerij pri oblikovanju človeške figure je veljalo za znak kvalitete že vsaj od sredine 5. stoletja pr. n. št. ko jih je v svojem kipu, bolj znanem kot Kanon, udejanil Poliklejt. Uporabe določenih sorazmerij pa ni prikazal samo v praksi, ampak je domnevno o njej pisal tudi v svojem istoimenskem spisu. Ta se sicer ni ohranil, vendar pa lahko o njegovi vsebini sklepamo posredno iz omemb v drugih besedilih. Grški zdravnik Galen in rimski gradbenik in teoretik Vitruvij tako omenjata, da je Poliklejt $v$ Kanonu v zvezi s človeškim telesom in njegovim upodabljanjem razmišljal o sorazmernosti in simetriji - dveh matematičnih pojmih (Williams, 2004, 28-29). Za problem grškega kanona v kiparstvu gl. tudi Spivey (1996, 36-41). 
po Plinijevem mnenju pomemben tudi zato, ker se je prav pod njegovim vplivom po celotni Grčiji razširila navada poučevanja risanja. Risanje naj bi prav zato postalo celo del splošne izobrazbe in bilo uvrščeno med svobodne umetnosti (Naravoslovje, 35, 36).

Za umetnika je bilo seveda še pomembneje, da je obvladal svojo osnovno veščino, likovno oblikovanje. Iz Plinijevega besedila je očitno, da mnogi umetniki svoje veščine niso obvladali le v praksi, ampak so bili sposobni svoje znanje podpreti tudi teoretsko. Med slikarji teoretiki Plinij omenja med drugimi Apela, ki je domnevno napisal knjigo o veščini slikarstva ( $\mathrm{Na}$ ravoslovje, 35, 36), in Evfranorja, ki je menda pisal knjige o proporcih in barvah (Naravoslovje, 35, 40). Od kiparjev so bili po Plinijevih navedbah teoretsko dejavni na primer Poliklejt, avtor znamenitega Kanona, Menemah, Ksenokrat in Antigon, ki so pisali o lastnem delu (Naravoslovje, 34, 19), in nenazadnje tudi Pazitel, ki naj bi napisal razpravo o najbolj znanih svetovnih umetninah v kar petih delih (Naravoslovje, 36, 4). ${ }^{10}$

Za uveljavitev vsakega umetnika pa je bila seveda odločilna njegova dejanska spretnost. Obvladovanje veščine je bil v prvi vrsti božji dar. ${ }^{11} \mathrm{Za}$ razvijanje in izpolnjevanje tega daru pa je bil odgovoren vsak posameznik. Prepričanje, da je umetnikov uspeh odvisen (tudi) od njegovega lastnega

10 Mnoge od piscev teoretskih razprav, ki jih omenja v besedilu Naravoslovja, Plinij navaja tudi kot svoje vire v spremljevalnih seznamih. Kot opozarja Jerome J. Pollitt, se da vsaj za nekatere od omenjenih besedil dobro rekonstruirati, do kod se nanje naslanja (Pollitt, 1995, 2-3).

11 Najstarejše ohranjene omembe tega, kar bi zdaj imenovali likovno udejstvovanje, pričajo o predstavi naših prednikov, da človekova ustvarjalnost prihaja od bogov. To misel jasno prepoznamo tudi v grški mitologiji, ki je polna zgodb o posameznikih, veščih takšnih ali drugačnih spretnosti.

Zgodba o predici Arahni skupaj s pripovedjo o kiparju Pigmalionu začrtuje okvir najstarejšega izpričanega dojemanja človekove ustvarjalnosti in obvladovanja različnih veščin. Obe zgodbi jasno pričata o tem, da so Grki ustvarjalnost razumeli kot božjo domeno. Če se je navadni smrtnik odlikoval po svoji ustvarjalnosti, obvladovanju te ali one veščine, je bilo jasno, da je svoj navdih in znanje dobil po volji bogov. Tega ni smel nikoli pozabiti. Kot kažeta Arahnina zgodba ali pa pripoved o Prometeju, ki je iz gline ustvaril ljudi in jih naučil različnih veščin in spretnosti, je bila kazen za spozabo ponavadi celo veliko hujša od smrti. Idejo o umetnosti kot "nadnaravni« veščini najdemo tudi pri Pliniju, tako neposredno v odlomkih, kjer govori o Naravi kot o umetniku - npr. artifex natura v knjigi o astronomiji in meteorologiji (Naravoslovje, 2, 66) in naturae rerum artificio v knjigi o žuželkah (Naravoslovje, 11, 1) - kot posredno v knjigi o cvetlicah, kjer omenja tekmovanje med Naravo in umetnostjo - certamen artis ac naturae (Naravoslovje, 21, 3). 
prizadevanja, je dobro izraženo v domnevnem življenjskem vodilu grškega slikarja Apela »Noben dan brez črte! «12 Prizadevnost se mu je očitno izplačala, saj mu je verjetno prav vztrajna vsakodnevna vaja v risanju omogočila, da je ob neki priliki, kakor obširno opisuje Plinij, premagal svojega sodobnika Protogena. ${ }^{13}$ Že nekaj strani pred opisano zgodbo pa Plinij pri predstavitvi slikarja Parazija razloži tudi, zakaj je po njegovem pomembno dobro obvladovanje risbe. Dobra obrisna črta naj bi slikarju omogočila, da doseže učinke, potrebne za kvalitetno sliko. Eden od njih je na primer iluzija na sliki sicer zakritih delov (Naravoslovje, 35,36$).{ }^{14}$ Obe zgodbi skupaj jasno kažeta, da Plinij kvaliteto slikarja enači z njegovo veščino realističnega upodabljanja.

Plinijevo opisovanje kvalitete posameznega likovnega ustvarjalca zaznamuje precejšnja formulaičnost. Dobro ilustracijo klišejskih predstav o tem, kakšno naj bi bilo dobro likovno oblikovanje, najdemo v tistem delu Naravoslovja, kjer Plinij opisuje razvoj slikarstva. V njem bralec vedno znova naleti na prigodo, zgrajeno okrog prevare, ki naj bi bila posledica vrhunskega obvladovanja realističnega upodabljanja. Plinij na primer poroča o vranah, ki so se prevarane hotele spustiti na naslikano streho (Naravoslovje, $35,7)$, o sliki tekača, ki je videti, kakor da se poti, in spet o drugi sliki teka-

12 Nulla dies sine linea! Prim. komentar $\mathrm{k}$ angleškemu prevodu Plinijevega Naravoslovja (Rackham, 1984, 323, op. c).

13 Plinij namreč opisuje, da se je Apel podal celo na otok Rodos, kjer je živel njegov veliki tekmec Protogen, da bi si v živo ogledal njegova dela, ki jih je poznal le po slovesu. Ker ga ob svojem obisku ni našel doma, mu je pustil zanimivo sporočilo - na platno naj bi naslikal eno samo ravno črto. Ko se je Protogen vrnil in natančno preučil naslikano črto, je takoj vedel, kdo ga je iskal. Nato naj bi Protogen vzel v roke čopič in natančno na Apelovo črto narisal v drugi barvi še eno, po Plinijevem poročanju tanjšo črto. Služkinji je naročil, da naj platno pokaže obiskovalcu, če bi se ta vrnil. Apel se je v resnici vrnil. Osramočen zaradi Protogenove črte je narisal z novo barvo še tretjo črto, ki je bila še tanjša od obeh prejšnjih. Protogen je po tem priznal, da je zadnja črta najtanjša, in sprejel svoj poraz (Naravoslovje, 35, 36). Zgodba pa se s Protogenovim priznanjem, da je Apel boljši od njega, ne konča. Po Plinijevih podatkih se je Protogen namreč odločil, da je treba platno s tremi črtami shraniti za naslednje rodove. Tako ga bodo lahko občudovali laiki, poleg tega pa bo v študijske namene na voljo tudi mlajšim slikarjem. Plinij dalje omeni, da se je platno dejansko ohranilo in je bilo sestavni del cesarske umetniške zbirke. Platno je bilo domnevno uničeno v prvem požaru cesarske palače na Palatinu leta 4 (Naravoslovje, 35, 36).

14 Plinijevo razumevanje pomena črte ni izvirno. V njem lahko prepoznamo Aristotelovo idejo, da je kvaliteta slikarstva odvisna od črte in ne barve (Poetika, 1450 b). 
ča, ki od zadihanosti »lovi zrak« (Naravoslovje, 35, 36), o portretu Aleksandra Velikega s strelo, ki je bil menda tako resničen, da so njegovi prsti in strela »gledali iz slike« (Naravoslovje, 35, 36), o pticah, ki jih je prestrašila okrog drevesa ovita upodobitev kače (Naravoslovje, 35, 37) in o sliki sadja in grozdja, ki je bila tako realistična, da nihče ni mogel ločiti med pravim sadjem in sliko (Naravoslovje, 35, 44). Zanimivo je še njegovo pričevanje o Apelovih portretih, ki naj bi bili tako resnični, da so lahko t. i. fiziognomisti ${ }^{15} \mathrm{iz}$ njih napovedovali, koliko je portretiranec star in koliko let bo še živel (Naravoslovje, 35, 36). ${ }^{16}$

Zgodovino slikarstva in kiparstva, kot jo v 34., 35. in 36. knjigi Naravoslovja prikaže Plinij, lahko torej razumemo kot sosledje stopenj, za katerega naj bi bilo značilno postopno povečevanje realizma pri upodabljanju. Tako zamisel o več zaporednih stopnjah, v katerih se udejanja umetnostnozgodovinski razvoj, kot tudi enačenje stopnje razvoja slikarske oz. kiparske veščine s stopnjo realizma pri upodabljanju izvirno nista Plinijevi, ampak sta veliko starejši. Nanju naletimo pri številnih antičnih piscih, ki so obravnavali problem zgodovine likovnega ustvarjanja (Pollitt, 1995, 4-6; Trautwein, 1997, 22). Prvi, ki je domnevno uporabil model razvoja likovne umetnosti z zaporednimi stopnjami, je bil grški mislec Demokrit. Prav on je sploh »odkril« zgodovinskost umetnosti. Po njegovem naj bi človeštvo od svojih primitivnih začetkov zaradi potrebe po razvoju postopno napre-

15 Fiziognomisti so bili prerokovalci, ki so napovedovali človekovo usodo iz njegovega obraza.

16 Plinij veščino realističnega upodabljanja izbranega motiva pogosto poveže tudi z domnevnimi tekmovanji med posameznimi slikarji sodobniki. Merjenje moči med Zevksisom in Parazijem se je na primer začelo z Zevksisovo sliko grozdja. Ta je bila tako resnična, da je prevarala zmedene ptice. V nadaljevanju je menda Parazij na platno naslikal zaveso tako dobro, da ga je nestrpni Zevksis prosil, naj že vendar razkrije svojo sliko, da si jo bo lahko ogledal. Ko je spoznal svojo zmoto, je tekmecu priznal zmago (Naravoslovje, 35, 36). Plinij pa poroča še o eni tovrstni prigodi, povezani z Zevksisom. Nekaj let po opisanem dogodku je Zevksis naslikal sliko otroka z grozdjem, ki je prevaralo ptice. Vendar pa Zevksis tega ni razumel kot priznanje kvalitete svojega dela. Nasprotno, prepričan je bil, da slika kot celota ni uspela. Če bi namreč tudi otroka naslikal, tako kot je treba, bi se ga morale ptice prestrašiti (Naravoslovje, 35, 36). Pogostost sklicevanja na opisane klišejske prigode nas pripelje do sklepa, da je Pliniju domnevna veščina realističnega upodabljanja pri posameznem ustvarjalcu pomembna predvsem za utemeljevanje njegove kvalitete. Plinij pri opisu življenja in dela slikarja Apela celo navaja, da je znameniti slikar svojo sliko konja postavil pred prave konje, ki so prevarani zaradi realizma podobe zarezgetali. Od takrat dalje, zaključi Plinij, je sposobnost tovrstne prevare postala trden dokaz umetniške veščine (Naravoslovje, 35, 36). 
dovalo in doseglo določeno stopnjo kulture, luksuza in bogastva. V okviru splošnega razvoja so se razvijale tudi obrti, pesništvo, glasba in človekovo likovno udejstvovanje. Demokrit je zavrnil ustaljeno prepričanje, da so najstarejši kipi, slike in stavbe delo Bogov. Prvi umetnik je bil po njegovem mnenju Dedal, o katerem je domnevno pisal že Homer. Demokrit je pri opisovanju likovnih artefaktov poleg zamisli o razvoju prvi uporabil tudi metodo primerjanja. ${ }^{17}$

Oboje je po njem prevzel »oče umetnostne zgodovine« Ksenokrat iz Aten. ${ }^{18}$ Ksenokrata je zanimala sistematika. Model večstopenjskega razvoja je uporabljal predvsem teoretsko, saj ga dejanski datumi in biografski podatki niso zanimali (Schweitzer, 1963, 110). Zato pa sta model, v katerem začetni, primitivni stopnji sledijo prehodna obdobja, obdobje razcveta oz. izpolnitve in končno obdobje zatona, bolj zgodovinsko uporabljala Mark Tulij Cicero in Mark Fabij Kvintilijan. Cicero je v svojem Brutu zagovarjal misel, da za vse umetnosti velja pravilo počasnega napredovanja oz. izpopolnjevanja (Brut, 70-71). Idejo je uresničil v svojih orisih razvoja grškega slikarstva in kiparstva. Oba je vzpostavil s pomočjo resničnih osebnosti, zgodovinsko izpričanih slikarjev in kiparjev. Posamezne stopnje razvoja je določil z opisom lastnosti njihovih del. Isti model je uporabil tudi Kvintilijan v svojem najpomembnejšem delu Izobraževanje govornika (12, 10, 1-9), v katerem je razvoj slikarstva in kiparstva opisal z naštevanjem posameznih avtorjev in njihovih del. Oba sta kot merilo napredka posamezne stopnje v razvoju razumela povečevanje realizma pri upodabljanju.

Plinij se je torej pri svojem opisovanju postopnega razvoja slikarstva in kiparstva držal preizkušenega in dolga stoletja uveljavljenega večstopenjskega modela. Ta ugotovitev nas po mnenju večine raziskovalcev ne bi smela presenečati vsaj iz dveh razlogov. Najprej je tu dejstvo, da Plinij ni pisal »umetnostnozgodovinskega spisa. Njegov opis razvoja posameznih likovnih zvrsti je le sestavni del obširnega enciklopedičnega pregleda »naravne zgodovine«. Zbrano znanje in podatke je črpal pri številnih piscih,

$17 \mathrm{Za}$ analizo Demokritove »umetnostnozgodovinske« misli gl. Schweitzer (1963, 113-114).

18 Tako ga imenuje Bernhard Schweitzer. Ksenokrat je bil po njegovem mnenju tisti, ki je prekinil tradicijo klasičnega pristopa k obravnavi likovnega ustvarjanja in vanjo uvedel novosti helenistične filozofije (Schweitzer, 1963, 110). 
ki so se ukvarjali s posameznimi področji. Presenetljivo bi prej bilo, če bi Plinij prav pri opisovanju likovne umetnosti prispeval lasten, izviren metodološki prispevek.

Drugi razlog, da nas, po mnenju številnih preučevalcev Plinija, njegova tradicionalnost pri opisovanju razvoja posameznih likovnih zvrsti ne bi smela presenetiti, je sorazmerno objektivizirani in neoriginalni značaj virov, iz katerih je črpal. Za večino antičnih spisov, ki obravnavajo likovno umetnost, je značilno predvsem opisovanje ter povzemanje starejših virov in morebitnih ustnih informacij. Njihovi avtorji so menda le redko izrekli kakršnokoli osebno sodbo o nekem umetniku ali njegovem delu. Z drugimi besedami, antični avtorji niso kazali nobene želje ali potrebe po originalnem prispevku k razvoju »umetnostnozgodovinske« teorije (Pollitt, 1990, 2).

Tudi dejstvo, da je Plinij svoj opis razvoja slikarstva in kiparstva zasnoval kot niz anekdot o posameznih ustvarjalcih, naj po ustaljenem prepričanju stroke ne bi bilo nenavadno. Prav tako kot posamezni dogodki, ki jih v njih omenja, tudi sam model zgodovinskega prikaza v obliki zbirke anekdot ni bil izvirno njegov. Zanimanje za izredne osebnosti in senzacionalne zgodbice iz njihovih življenj je bilo značilno na primer že za Durisa s Samosa. Durisovo razpravo o slikarstvu najdemo tudi na Plinijevem seznamu virov, iz katerih je črpal. Prav po njem je Plinij povzel na primer omenjeni podatek, da grški kipar Lizip ni imel učitelja, ampak se je učil neposredno od Narave. Tudi v drugih prigodah iz življenja slavnih umetnikov je moč prepoznati vpliv Durisovega besedila. Še več, Durisa bi morali razumeti kot avtorja večine anekdotičnih podatkov o slikarjih in kiparjih, ki jih najdemo pri Pliniju (Pollitt, 1990, 6).

Če strnemo povedano, dobimo podobo, ki si jo je stroka ustvarila o Pliniju, njegovem Naravoslovju in grški umetnosti, kot naj bi jo v njem bralcu predstavljal avtor. Ta podoba ima dva pomembna poudarka. Prvi je prepričanje, da Plinijevo besedilo ni več kot le zbirka podatkov, ki jih je avtor pobral pri starejših piscih (Pollitt, 1990, 6). S tem je bil Pliniju - ne samo kot piscu »umetnostnozgodovinskih« odlomkov Naravoslovja, temveč kot avtorju celotnega besedila - odvzet položaj pravega avtorja, njegovo delo pa je dobilo pečat drugorazredne kompilacije (Carey, 2003, 10). Drugi poudarek tradicionalnega razumevanja Plinijevega Naravoslovja je ideja, da Plinijevi odlomki o posameznih likovnih zvrsteh enoznačno odsevajo 
odnos antičnega človeka, natančneje odnos rimskega izobraženca, ki pa je enak odnosu Grka (prim. npr. Isager, 1998, 14), do grške likovne tvornosti. Ta odnos naj bi temeljil predvsem na občudovanju veščine verističnega oblikovanja oz. upodabljanja, ki je zato postala celo vrednostno merilo.

Postavlja se vprašanje, ali je tovrstno razumevanje Plinija kot avtorja pa tudi njegovega Naravoslovja upravičeno. Lahko celotno Naravoslovje oz. Plinijeve zapise o slikarstvu in kiparstvu beremo še kako drugače?

III.

Največji problem tradicionalnega branja Plinijevega Naravoslovja je, da se ga ponavadi bere per partes, torej po posameznih odsekih, ki bolj ali manj ustrezajo sodobni razmejitvi védnosti v okviru posameznih znanstvenih disciplin. Kljub nekaterim novejšim raziskavam, ki izrecno poudarjajo nujnost branja celotnega besedila Naravoslovja (prim. npr. Isager, 1998; Carey, 2003), tako tudi med raziskovalci antične likovne umetnosti še vedno prevladuje prepričanje, da se ključ do razumevanja Plinijevega odnosa do likovne tvornosti lastnega časa in preteklih obdobij skriva v knjigah, v katerih naj bi avtor analitično opisoval razvoj slikarstva in kiparstva.

Tak pristop k Plinijevemu besedilu ne more prispevati celovitega vpogleda v njegov odnos do likovne umetnosti vsaj iz dveh razlogov: prvič zaradi svoje osredotočenosti na točno določene dele Naravoslovja raziskovalci te iztrgajo iz okvira celotnega besedila, s čimer v resnici ustvarijo povsem "nova besedila «, in drugič, ker branje zgolj tistih odlomkov Naravoslovja, v katerih Plinij opisuje posamezne zvrsti likovne umetnosti, vključuje bolj ali manj izrazito idejo o Pliniju kot umetnostnem zgodovinarju, torej o avtorju, ki ga zanima umetnostna produkcija v povsem sodobnem smislu besede.

Jasno je, da Plinij ni nameraval pisati umetnostnozgodovinske razprave. Svoje poglede na likovno tvornost je uvrstil v vsebinsko veliko širše zastavljeno delo, še več, likovne tvornosti ne obravnava celovito, marveč po posameznih zvrsteh glede na uporabljane materiale. $S$ takim pristopom do obravnave likovne tvornosti Plinij pravzaprav ni kakšna posebna izjema med svojimi sodobniki. 
Antična besedila, v katerih so pisci obravnavali posamezne likovne zvrsti, bi po ustaljenem mnenju stroke lahko razvrstili v štiri skupine (Pollitt, 1990, 6-9). V prvo, najbolje ohranjeno skupino uvrščamo besedila, v katerih so njihovi avtorji zbrali podatke iz starejših virov. V njih lahko najdemo najrazličnejše biografske, tehnične in anekdotične podatke o življenju in delu posameznih likovnih ustvarjalcev. V to skupino sodijo poleg Pavzaniasovega Opisa Grčije tudi obravnavani odlomki Plinijevega Naravoslov$j a$. V drugi skupini so besedila, $\mathrm{v}$ katerih likovna umetnost nastopa le kot analogija ali celo neposreden navdih za literaturo. Tovrstni besedili sta na primer že omenjena Ciceronov Brut in Kvintilijanovo Izobraževanje govornika. Tretjo skupino tvorijo razprave moralnih estetikov, v katerih avtorji razmišljajo o umetnosti in njenem vplivu na človekovo obnašanje in moralno ozaveščenost. Najbolj znana moralna estetika sta brez dvoma Platon in Aristotel. Zadnja skupina so razprave samih likovnih ustvarjalcev, za katere je značilna predvsem osredotočenost na oblikovne probleme in tehnične postopke. Bolj kot razprave o razvoju posameznih likovnih zvrsti jih moramo torej brati kot tehnične priročnike. Nekatere tovrstne spise navaja tudi Plinij kot svoje vire (na primer Ksenokrata iz Aten, Antigona in Pazitela).

Dejstvo torej je, da antika ni poznala umetnostnozgodovinske razprave kot take, saj antičnemu človeku razvoj likovnega ustvarjanja ni pomenil avtonomnega področja intelektualnega raziskovanja. Eden pomembnejših razlogov za to je bilo prav gotovo antično dojemanje tega, kar zdaj s skupnim izrazom imenujemo likovna umetnost. Izraza $\tau \dot{\varepsilon} \chi v \eta$ oz. ars za antičnega človeka namreč nista imela le drugačnega vsebinskega pomena, temveč se od modernega izraza umetnost razlikujeta celo $\mathrm{v}$ kategorialnem smislu: če zdaj pod pojmom umetnost najprej razumemo zbir artefaktov, za katere veljajo točno določena merila, pa je antični človek z izrazoma $\tau \dot{\varepsilon} \chi v \eta$ oz. ars označeval dejavnost (Tatarkiewicz, 2000, 9-16).

To se dobro kaže tudi v Plinijevih opisih slikarstva in kiparstva. Plinij "zgodovine« obeh likovnih zvrsti ne obravnava $\mathrm{z}$ vidika razvoja nekega bolj ali manj abstraktnega umetniškega sloga, kot se kaže na posameznih umetniških delih, ampak kot neprestano izpopolnjevanje veščine oblikovanja, natančneje veščine oblikovanja človeške figure. Razvoj slikarskega oblikovanja človeške figure (po njegovi začetni stopnji obrisovanja človeške sence; slik. 5) začenja Evmar iz Aten, ki naj bi prvi upodabljal ženske in moške 
figure različno, ${ }^{19}$ nadaljuje pa Kimon, ki je izboljšal upodabljanje njihovih sklepov in žil. Kimon je naredil korak naprej tudi pri oblikovanju draperije. Njegova prizadevanja je dopolnil Polignot s Tazosa. Polignot je poleg tega človeško figuro prvi upodobil $\mathrm{z}$ odprtimi usti in razkritimi zobmi. Postopnim izboljšavam realističnega upodabljanja človeške figure lahko dalje sledimo tudi pri pomembnejših slikarjih, o katerih se Plinij obširneje razpiše.

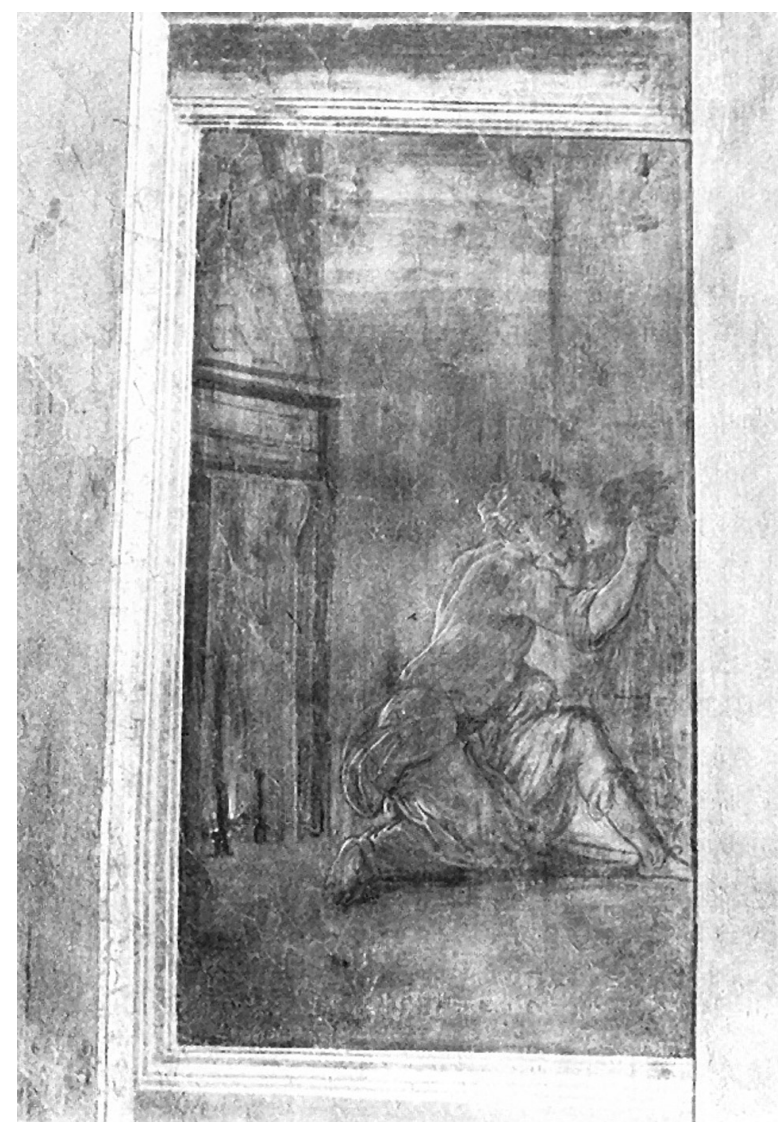

slik. 5: Giorgio Vasari, Iznajdba risanja, kmalu po 1541, Casa Vasari, Sala del Trionfo della Virtù, Arezzo vir: Rubin (1995)

19 Kot pojasnjuje H. Rackham v opombi k svojemu prevodu Plinijevega Naravoslovja, je treba $\mathrm{v}$ tej avtorjevi opazki najverjetneje razumeti namig na eno od značilnosti vaznega slikarstva: od 7. stol. pr. n. št. so slikarji ženske figure slikali svetlejše polti kot moške (Rackham, 1984, $302)$. 
Zevksis iz Herakleje in njegov tekmec Parazij iz Efeza pa veliki Apel s Kosa in Protogen z Rodosa, vsak je prispeval svoj kamenček v mozaik vseskozi napredujočega in izpopolnjujočega se verizma (Naravoslovje, 35, 35).

Podoben vtis dobi bralec tudi pri Plinijevem opisu razvoja kiparstva. Tudi za razvoj "plastične umetnosti $\aleph^{20}$ je bila namreč po avtorjevem mnenju odločilnega pomena iznajdba načina, kako iz gline oblikovati človeško podobo (Naravoslovje, 35, 44). Odkritje je najprej vplivalo na razvoj kiparstva v bronu, ki je sčasoma postajalo v oblikovanju vse bolj smelo - napredek se je najbolj očitno kazal v vse večjih merah kipov in je svoj vrhunec brez dvoma dosegel s t. i. kolosi (Naravoslovje, 34, 17 in 18). Tudi nekoliko poznejši razvoj kiparstva $\mathrm{v}$ kamnu je bil po Plinijevem mnenju povezan $\mathrm{s}$ postopnim povečevanjem verizma človeške figure (Naravoslovje, 34, 19). ${ }^{21}$ Za Mirona avtor celo dobesedno navaja, da je bil prvi kipar, ki je "povečal realizem « v svoji veščini! ${ }^{22}$

Plinija torej ne zanima razvoj sloga, kot se kaže v posameznih artefaktih, ampak napredovanje veščine njihovih avtorjev. Njegovih opisov razvoja posameznih likovnih zvrsti - podobno kot kateregakoli ohranjenega tovrstnega besedila, nastalega $\mathrm{v}$ antičnem času -, pa naj se zdijo še tako »domači«, zato ne moremo brati kot sodobne umetnostnozgodovinske razprave. Odlomki Plinijevega Naravoslovja, v katerih opisuje kiparstvo in slikarstvo, so v tem pogledu povsem paradoksalni: po eni strani so nedvomno osnova, iz katere se je razvil poznejši umetnostnozgodovinski model stopenjskega razvoja likovne umetnosti, po drugi strani pa jih seveda nikakor ne moremo brati kot zgodovinski opis razvoja antične likovne tvornosti, ki se je razvijala preko zaporednih slogovnih (oblikovnih) stopenj. ${ }^{23}$

20 Plinij za modeliranje v glini uporablja grški izraz plastice (Naravoslovje, 34, 16 in 35, 48).

21 Posledica neprestanega poudarjanja napredovanja veščine oblikovanja, pa najsi je šlo za veščino risanja, modeliranja ali klesanja, je bila po mnenju nekaterih avtorjev dejstvo, da naj bi današnji bralec Plinijevo besedilo bolj kot umetnostno zgodovino bral kot zgodovino znanosti oz. tehnike (Williams, 2004, 10).

22 ... primus hic multiplicasse veritatem videtur, ... (Naravoslovje, 34, 19).

$23 \mathrm{Na}$ dejstvo, da so si poznejši raziskovalci krčevito prizadevali iz Plinijevih opisov posameznih likovnih zvrsti narediti umetnostnozgodovinsko besedilo, in katere pomanjkljivosti njegovega besedila so morali pri tem „popravljati“, je opozorila npr. tudi Sorcha Carey (2003, 14). 
Samo celovito branje Plinijevega Naravoslovja lahko prispeva k ustreznejši interpretaciji tako celotnega besedila kot tudi njegovih posameznih delov. Analiza zgradbe posameznih knjig oz. poglavij in njihove umestitve $\mathrm{v}$ okviru celotnega besedila, osredotočenje na uporabo posameznih besed in besednih zvez $\mathrm{v}$ različnih okvirih in nenazadnje temeljita analiza virov, pri katerih Plinij črpa, s poudarkom na idejah, ki si jih pri svojih virih izposoja, in načinu, kako jih splete v svojo lastno pripoved, omogočajo novo razumevanje Plinija, avtorja in tudi ciljev, ki jih je skušal doseči s svojim delom. Poglejmo nekatere interpretativne možnosti, do katerih nas lahko pripelje tovrstno branje Plinija.

Jacob Isager je že v uvodu svoje razprave poudaril potrebo po novem, celovitem pristopu k Plinijevemu Naravoslovju (Isager, 1998, 17). To je skušal doseči predvsem z zares podrobno analizo zgradbe vseh tistih delov Naravoslovja, kjer je govor o likovni umetnosti. Pokazal je, da je Plinij opise posameznih likovnih zvrsti zasnoval po istem vzorcu (Isager, 1998, 78-79, 96, 113): najprej upraviči obravnavo posamezne veščine (čeprav je bila $\mathrm{v}$ njegovem času tako rekoč že »mrtva«, pa je imela v preteklosti velik pomen), po navedbi njenih začetkov Plinij nato poda pregled največjih grških mojstrov veščine v kronološkem zaporedju, sledi mu pregled manj znanih avtorjev po abecednem redu. Kjer se le da, Plinij navaja dela obravnavanih grških mojstrov, ki se jih da videti v Rimu. Pri posameznih delih navede le njihovo ime in nahajališče, vzdrži pa se vsakršne vrednostne oz. estetske (slogovne) sodbe. Plinij pogosto navaja tudi rimska dela, da bi nekako uravnotežil svoj pregled, vendar pa v teh primerih izrecno poudarja njihovo funkcijo, predvsem pa praviloma ne omenja njihovih avtorjev (Isager, 1998, 93, 105).

Najpomembneje se Isagerju zdi na eni strani vedno znova ponavljajoče se Plinijevo poudarjanje javne funkcije likovne umetnosti, na drugi strani pa njegovo prav tako ponavljajoče se vzpostavljanje razlike med uporabo likovne umetnosti v daljni preteklosti (raba) in v njegovem lastnem času, predvsem času cesarja Nerona (zlo-raba) (Isager, 1998, 78-79, 113). Po Isagerjevem mnenju ta dva poudarka nedvoumno kažeta na to, da Plinij v svojih opisih posameznih likovnih zvrsti ni samo podal slike o družbeni in politični vlogi umetnosti v okviru rimske družbe, ampak je jasno poudaril tudi politično sporočilo svojega časa: po obdobju etičnega kolapsa Nerono- 
ve dobe naj bi obdobje vladanja Tita in Vespazijana rimski državi povrnilo moralno odličnost (Isager, 1998, 229).

Še korak dlje proti povsem celovitemu branju Plinijevega Naravoslovja je naredila Sorcha Carey, ki se ni omejila le na analizo obravnave posamezne teme skozi celotno besedilo, kot je to storil Isager, ${ }^{24}$ temveč je $\mathrm{Na}$ ravoslovje $\mathrm{v}$ resnici brala kot zaključeno celoto. Pri tem ni bila pozorna le na vsebinske, marveč tudi povsem jezikovne podrobnosti. Ugotovila je, da je Plinij za opisovanje narave oz. njenih »dosežkov« uporabljal iste besede, kot jih najdemo v njegovih opisih posameznih likovnih zvrsti (Carey, 2003, 134-136). Plinijeve primerjave človekove dejavnosti in Narave so po njenem mnenju torej znak, da je bilo vzpostavljanje odnosa med človekom in Naravo, ki ga je Plinij razumel kot moralno nasprotje (raba/izkoriščanje), pravzaprav bistveni del avtorjevega razumevanja rimske identitete (Carey, 2003, 104). Tudi Careyjeva poudarja, da se je Plinij v svojih bolj sistematičnih opisih likovnih zvrsti sicer osredotočil na razvoj slikarstva in kiparstva v Grčiji, vendar pa je avtor svojo pripoved sestavil tako, da je poudarek brez dvoma na grških delih v Rimu (Carey, 2003, 181-182). Careyjeva je natančno analizirala tudi okvire, $v$ katerih se pojavljajo posamične omembe umetniških del v drugih knjigah Naravoslovja. Ugotovila je, da so Pliniju posamezna umetniška dela kot nekakšna »sidra«, ki njegov opis Narave trdno umeščajo v fizično stvarnost (Carey, 2003, 43).

Povezava vseh treh poudarkov - Plinijevo prizadevanje, da bi opredelil rimsko identiteto, sistematični opisi grškega slikarstva in kiparstva, ki temeljijo na opisovanju grških artefaktov v Rimu s posebnim poudarkom na njihovi »uporabi«, in nenazadnje uporaba posameznih umetniških del za umeščanje vsega, kar je ustvarila Narava, v okvir fizične stvarnosti - je avtorici omogočila, da je oblikovala svoje razumevanje Plinijevega Naravoslovja. Po njenem mnenju je Plinij v svojem obširnem delu skušal uresni-

24 Do take obravnave Naravoslovja je Isagerja verjetno vodilo njegovo prepričanje, da je Plinij Naravoslovje zasnoval kot referenčno delo, ki naj bi ga bralec dejansko bral po odsekih, glede na temo, ki ga je pač zanimala (Isager, 1998, 18). Sicer opozarja na to, da so Plinijevi opisi posameznih zvrsti likovne umetnosti v knjigah od 33. do 37. del večje celote, ki pa se ji Isager v nadaljevanju približuje selektivno - v preostalih knjigah bere le tisto, kar je na tak ali drugačen način povezano z likovno umetnostjo (problem "ustvarjalca " (artifex) in iznajditelja (inventor) pa tradicija zbiranja grških artefaktov v okviru rimske družbe ipd.). 
čiti idejo Italije kot najnaprednejše države, pri čemer je imela pomembno vlogo prav likovna umetnost (Carey, 2003, 181-182).

Po mnenju Isagerja in Careyjeve moramo torej Plinijevo Naravoslovje brati kot izrazito politično obarvano delo. Opisi grške likovne umetnosti kot njegovi sestavni deli so zato tudi sami politično obarvani. Ne samo način, kako jih je Plinij umestil v svoj pregled, ampak tudi, kaj je uvrstil v svoje preglede grškega slikarstva in kiparstva ter kako obsežni so ti opisi, katere grške avtorje je omenil, katera njihova dela so se mu zdela dovolj pomembna, da jih opiše, in nenazadnje, kakšne besede je pri tem uporabljal, vse skupaj je plod temeljitega Plinijevega premisleka.

Da Naravoslovje ni nekakšno nevtralno besedilo, v katerem je Plinij zgolj zbral in sistematiziral vse znanje svojega časa, kaže nenazadnje tudi podrobna analiza virov, na katere se v njem sklicuje. Prav opisi grške umetnosti so še posebej dober primer jasne politične obarvanosti celotnega besedila. Plinij je svoj opis razvoja grškega likovnega ustvarjanja deloma naslonil na delo Ksenokrata iz Aten. Ta je svoj petstopenjski razvoj slikarstva začel z Apolodorom, nadaljeval z Zevksisom, Parazijem in Evfranorjem, vrh pa naj bi slikarstvo doseglo z Apelom. Tudi razvoj kiparstva je razdelil na pet glede na napredek sledečih si stopenj. Začenjal naj bi ga Fidija, nadaljevali Poliklejt, Miron in Pitagora, končal pa Lizip. Že bežen pogled na oba seznama pokaže, da po Ksenokratovem mnenju vrh likovnega udejstvovanja pomenita dva pripadnika znamenite Sikionske umetnostne šole, Apel in Lizip. Ker je bil tudi sam učenec te šole - mogoče celo učenec Evtikrata, sina samega Lizipa (Naravoslovje, 34, 19) - nas ne sme presenetiti, da je Ksenokrat kot vrh tega, kar človek lahko doseže v likovnem udejstvovanju, postavil delo svojih predhodnikov oz. učiteljev (prim. npr. Pollitt, 1990, 3).

Ko Plinij povzema Ksenokratov model postopnega razvoja grške likovne umetnosti, ki doživi vrhunec s posameznimi pripadniki Sikionske šole, pa dobi vsa stvar še dodaten politični pomen. Apel in Lizip namreč nista bila le pripadnika Sikionske šole. Veliko pomembnejša sta bila kot dvorna umetnika Aleksandra Velikega. Ne moremo sicer zanikati dovršenosti njune veščine oz. ugleda, ki sta ga očitno uživala med svojimi sodobniki. Vendar pa hkrati tudi ne moremo mimo pomembne vloge, ki jo je imela njuna umestitev v sam vrh antične likovne tvornosti, pri brez dvoma dobro 
premišljenem prizadevanju helenističnih učenjakov, da bi čas Aleksandra Velikega (na pol barbarskega Makedonca!) obveljal za obdobje vrhunca grške civilizacije (Elsner, 1995, 15-16). Razglasitev Aleksandrovih dvornih umetnikov za vrh razvoja grške likovne umetnosti moramo v veliki meri torej razumeti kot politično zaznamovano.

Plinijevega prevzema Ksenokratovega modela razvoja grškega slikarstva in kiparstva torej nikakor ne moremo razumeti le kot nevtralno sklicevanje na starejše vire. Ne samo iz opisa posameznih likovnih zvrsti, pač pa tudi iz drugih delov njegovega besedila je jasno, da je Plinijevo Naravoslovje namerna sinteza dolgoletnega dela učenjakov, ki so delovali v okviru posameznih helenističnih dvorov. Jasneje Plinij svojega stališča do polpretekle zgodovine ne bi mogel izraziti.

IV.

Vrnimo se k Fidiji in vprašanju, kaj lahko sploh izvemo o človeku, za katerim se je ohranila le razbita skodelica. ${ }^{25}$ Začnimo z njegovim delom. Njegovi dve, po mnenju vseh antičnih piscev, ki ju omenjajo, najpomembnejši deli - hrizelefantinska kolosa Atene in Zevsa (slik. 2 in 3) - se nista ohranili. Poznamo ju le iz mnogo manjših in mlajših posnetkov, ki so povrh vsega še iz drugih materialov. Podobno velja tudi za njegova manjša dela - nekaj jih poznamo iz rimskih kopij, druge iz upodobitev na kovancih, spet tretje pa celo samo iz opisov v različnih pisnih virih (prim. Pollitt, 1990, 53-65).

Edino kolikor toliko ohranjeno delo, ki je dolgo časa veljalo za Fidijevo, je Partenonski friz, za katerega pa zdaj velja soglasje, da je bil Fidija pri njegovi izdelavi udeležen le kot nadzornik. Ohranjena dela torej nikakor ne zadostujejo, da bi lahko umetnostna zgodovina povedala karkoli o Fidiji kot avtorju. ${ }^{26} \mathrm{O}$ Fidiji poročajo tudi številni pisni viri. Vendar pa je precej-

25 Edini ohranjen materialni vir, povezan s Fidijem, je skodelica $\mathrm{z}$ vrezanim lastnikovim imenom, ki mu je domnevno pripadala. Nemški arheologi so namreč leta 1958 med arheološkimi izkopavanji v Olimpiji v ruševinah klesarske delavnice našli glazirano posodico (slik. 6), ki ima na dnu vrezan napis $\Phi E I \Delta I O$ EIMI (Pripadam Fidiji; slik. 7). Skodelica naj bi potrjevala domnevo, da je šlo za Fidijevo delavnico (Pollitt, 1990, 56; Boardman, 1996, 22; Spivey, 1996, 158).

26 Da običajna poznavalska metoda pri atribuciji Fidijevih del zato popolnoma odpove, najbolje kaže primer dveh bronastih kipov vojščakov iz Riaceja, ki so ju nekateri strokovnjaki na 
šnji del teh opisov sekundarne narave, kar pomeni, da so njihovi avtorji prepisovali drug od drugega. To je deloma razlog, da so opisi Fidijevega življenja in dela polni klišejskih podatkov. ${ }^{27} \mathrm{Kljub}$ temu se da $\mathrm{v}$ posameznih zapisih precej dobro izluščiti odnos, ki ga je vsakokratni pisec imel do Fidije oz. v kakšnem kontekstu je pisal o njem.

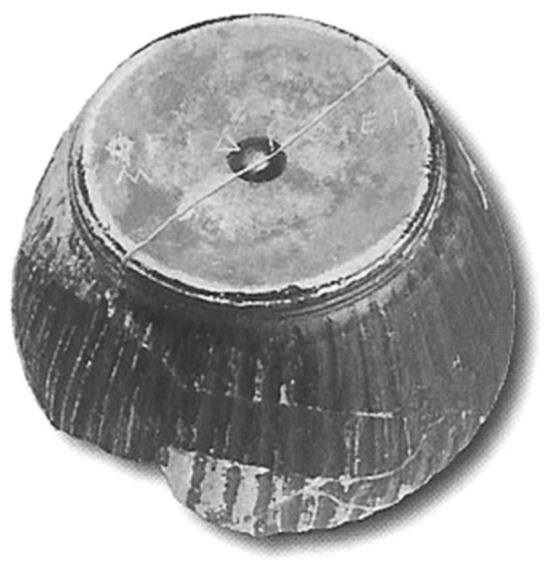

slik. 6: Glazirana skodelica, 440/430 pr.n.št., vrezanim Arheološki muzej, Olimpija muzej, Olimpija vir: http://www.lgpn.ox.ac.uk/image_ archive/vases/v5.htm

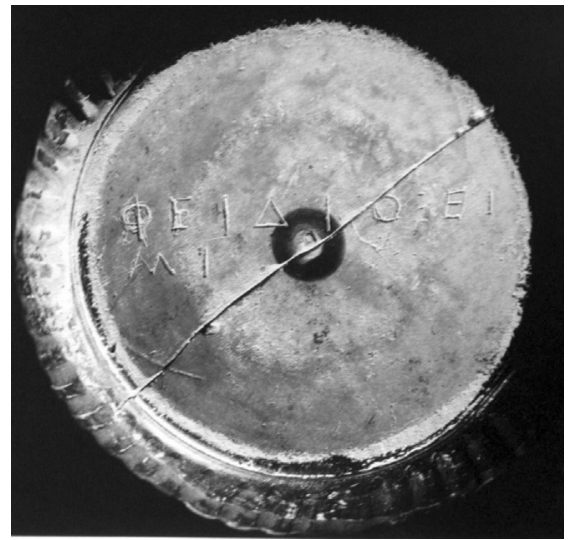

slik. 7: Dno glazirane skodelice z napisom, 440/430 pr.n.št., Arheološki vir: http://odysseyadventures.ca/ articles/olympia/figure 10 pheidiascup.htm

O Fidiji je pisal tudi Plinij. Bralcu ga ni predstavil z zaokroženo umetniško biografijo, kakršnih je Fidija deležen zdaj. Ker naj bi se Fidija ukvarjal tako s torevtiko kot tudi klesarstvom, ga Plinij omenja v različnih delih $\mathrm{Na}$ ravoslovja, pač v skladu s svojo delitvijo snovi, ki jo je v njem opisoval, pa tudi strukturo posameznega poglavja. Zato ga na primer obravnava v 34 .

podlagi slogovne analize pripisali prav Fidiji. Drugi se z atribucijo ne strinjajo in avtorstvo kipov pripisujejo bodisi Mironu bodisi nekaterim drugim kiparjem iz 5. stoletja pr. n. št. O tem gl. npr. Spivey $(1996,154)$. Dodatno problem slogovne analize Fidijevih del otežuje dejstvo, da Fidija vsaj svojih dveh največjih del prav gotovo ni mogel izdelati sam, temveč mu je pri tem morala pomagati cela ekipa pomočnikov. To postavlja pred raziskovalca vprašanje »slogov« posameznih pomočnikov, njihovega razmerja do »sloga « mojstra ipd.

27 Za pregled in komentar nekaterih pisnih virov o Fidiji gl. npr. Spivey $(1996,154-159)$. 
knjigi, v kateri govori o kovinah in njihovi obdelavi, in v 36. knjigi, v kateri opisuje kamen in njegovo uporabo, omenja pa ga še na drugih mestih. Plinij Fidijo bralcu prvič predstavi v 7. knjigi, v kateri našteva najrazličnejše človeške veščine in iznajdbe. Med najbolj vešče kiparje ga uvrsti zaradi njegovega Zevsa, ki naj bi za vse čase pričal o mojstrstvu svojega avtorja (Naravoslovje, 7, 38).

V 34. knjigi ga najprej predstavi kot avtorja hrizelefantinskega kolosa Zevsa, ki je izdeloval tudi kipe v bronu. Fidijevo ime skupaj z njegovim najpomembnejšim delom je Pliniju na tem mestu iztočnica za kronološko urejeni seznam vseh najpomembnejših grških kiparjev, ki so izdelovali bronaste kipe. V nadaljevanju ga omeni kot enega od udeležencev tekmovanja za najboljšega kiparja (Naravoslovje, 34,19$).{ }^{28}$ Šele nato sledi nekoliko daljši odstavek, ki je namenjen samo Fidiji.

Plinij Fidijo predstavi kot iznajditelja veščine torevtike in našteje nekaj njegovih del. Poleg Zevsa, ki naj bi ga nihče ne dosegel, omenja še drugi Fidijev kolos - Ateno Partenos, že omenjeno Amazonko iz efeškega svetišča, kip Dame s ključi, ${ }^{29}$ bronasto Ateno in tri dela, ki naj bi bila postavljena $\mathrm{v}$ rimskem svetišču boginje Fortune. Zanimivo pri zadnjih treh je, da Plinij za nobenega od njih ne pove, ali gre za izvirnik ali zgolj rimsko kopijo. Edini podatek, ki ga v zvezi s temi deli Plinij razkrije bralcu, je njihovo nahajališče, za dva pa še, kdo ju je dal postaviti v rimsko svetišče. Tovrstno opisovanje del grških avtorjev v Rimu je pri Pliniju običajno. Kljub temu da je pri precejšnjem delu teh del moralo iti za kopije, tega Plinij nikoli posebej ne poudarja (prim. Isager, 1998, 173 ss.), kar očitno kaže na to, da je imel do tega problema povsem drugačen odnos kot sodobni raziskovalec.

V nadaljevanju 34. knjige Plinij Fidijo še enkrat omeni kot iznajditelja torevtike in pa kot učitelja dveh manj pomembnih torevtov, Alkamena in Kolota, ki je bil njegov domnevno pomočnik pri Zevsu (Naravoslovje, 34,

28 Plinij takoj za seznamom najpomembnejših torevtov opiše »tekmovanje«, v katerem naj bi izbrali najboljšega kiparja vseh časov. V Artemidinem svetišču v Efezu so posvetili kipe Amazonk najpomembnejših kiparjev. Za najboljšega naj bi bil razglašen kip, ki bi ga vsi navzoči kiparji ocenjevalci uvrstili takoj za svojim delom. Zmagala naj bi Amazonka, ki jo je izdelal Poliklejt, sledili pa so ji kipi Fidije, Krezilasa, Kidona in Fradmona.

29 Morebiti je šlo za kip svečenice ali pa za Perzefono; gl. op. v angleški izdaji Plinija (Rackham, 1966-1984, 166). 
19). Da je Kolot pomagal Fidiji pri izdelavi olimpijskega kolosa, Plinij omeni še enkrat - v 35. knjigi, v kateri na samem začetku seznama najpomembnejših slikarjev omenja podatek, da je bil Fidija tudi slikar in je poslikal notranjo stran ščita nekega kipa Atene. Če ne Fidija sam, pa je bil po Plinijevih podatkih slikar njegov brat Panajnos (Naravoslovje, 35, 34).

K mojstru se Plinij vrne spet v 36. knjigi, kjer ga, čeprav gre za odlomek o kiparstvu v marmorju, prvič omenja spet kot iznajditelja torevtike - precej mlajše veščine od klesanja - in slikarstva. Plinij nadaljuje, da je bil tudi sam Fidija klesar in je izdelal kip Afrodite, ki je na ogled v Oktavijini hiši v Rimu. Plinij nato obravnava Fidijeve učence in njihova dela. Omeni, da je pri nekaterih delih svojih učencev sodeloval tudi Fidija, nekatera pa je izdelal celo mojster sam in dovolil, da so jih učenci predstavljali kot lastna. Plinij potem še enkrat poudari, da je Fidija najslavnejši kipar. Da bi upravičil slavo o njegovi nadarjenosti, nato opiše Fidijeve upodobitve na ščitu Atene Partenos in podstavku, na katerem je stala (Naravoslovje, 36, 4).

Plinij nam Fidijo predstavi kot človeka, ki je obvladal vsaj tri veščine, torevtiko (ars toreutice), slikarstvo (ars pingendi/picturae) in klesarstvo (ars scalpendi). Zadnji dve je baje celo iznašel, kar Plinij ponovi na več različnih mestih. To dejstvo nas ne preseneti, saj je rdeča nit celotnega Naravoslovja človekova (upo)raba Narave oz. vsega, kar mu ta ponuja. Posebno pozornost je avtor zato namenil tistim ljudem, ki so se izkazali za prve na kakem področju. Naslednji podatek, ki ga Plinij ponovi na več mestih, je, da je bil Fidija avtor Olimpijskega Zevsa. Tudi to nas ne sme presenetiti. Zevsov kolos je bil uvrščen med sedem svetovnih čudes antičnega sveta, zato ne preseneti Plinijevo ponavljanje, da gre za enega najslavnejših kipov na svetu.

Zanimivi sta Plinijevi omembi Fidijevega učenca, ki mu je pomagal pri delu, in dejstva, da je neki drug učenec smel z mojstrovim dovoljenjem njegova dela predstavljati kot svoja. Prva podrobnost povsem jasno kaže na to, da je delo Fidije - vsaj za hrizelefantinska kolosa je to zaradi njunih razsežnosti sicer samo po sebi umevno - potekalo prej skupinsko kot pa individualno. Druga podrobnost pa priča o tem, da avtorsko delo oz. po- 
jem osebnega »sloga« v antiki ni imel takega pomena, kot ga ima v okviru sodobne umetnostne zgodovine. ${ }^{30}$

Pozornemu bralcu končno ne more uiti razlika med Plinijevo obravnavo Fidije kot torevta in Fidije kot klesarja. Pri opisovanju Fidijevih dosežkov v oblikovanju v bronu Plinij našteva mojstrova dela, po možnosti skupaj s podatkom, kje jih je moč videti. Nasprotno pa pri opisu Fidije kot klesarja Plinij bralcu upravičuje Fidijev sloves z opisom klesarskih podrobnosti enega samega artefakta - ščita in podstavka Atene Partenos, ki jo je sicer omenil že med Fidijevimi torevtskimi deli. Tako različna obravnava Fidije na obeh področjih njegovega delovanja odseva drugačen pristop k obravnavi klesarstva na sploh. Pri opisu te veščine je namreč Plinij odstopil od trdne sheme, ki se je je držal pri opisu torevtike in slikarstva, in ki jo je tudi za klesarstvo sicer napovedal v prvi knjigi. Kakršnikoli so že bili razlogi za odstop od sheme, ${ }^{31}$ dejstvo je, da je Plinij Fidijo kot torevta obravnaval drugače kot Fidijo kot klesarja. To nam sicer ne pove dosti o Fidiji, je pa zanimiva iztočnica za razmišljanje o Pliniju in njegovem izboru.

\section{$\mathrm{V}$.}

Če zanemarimo nenavadne podrobnosti, povezane s problemom izvirnosti opisanih del in vprašanjem razmerja med mojstrom in njegovo delavnico, ter hkrati prezremo razlike v Plinijevi obravnavi Fidije na različnih področjih njegovega delovanja, lahko dobimo vtis, da Plinij bralcu Fidijo predstavi kot spretnega obrtnika, ki ne samo da je mojstrsko obvladal več veščin, ampak je vsaj eno od njih celo sam odkril. Njegovo mojstrstvo, jasno prepoznavno $\mathrm{v}$ vseh njegovih delih, predvsem $\mathrm{v}$ obeh hrizelefantinskih kolosih, naj bi mu prineslo slavo in občudovanje bližnje in daljne okolice.

30 Prav to neskladje je v zadnjih letih jedro razdora med raziskovalci grškega kiparstva. Na eni strani so tisti, ki trdijo, da je za grško kiparsko produkcijo prej kot individualizem značilna masovna proizvodnja na podlagi sorazmerno majhnega števila modelov, na drugi pa tisti, ki v najboljši tradiciji Meisterforschunga skušajo na vsak način identificirati slogovne značilnosti posameznih avtorjev, na podlagi katerih bi jim lahko odmerili mesto znotraj splošnega slogovnega razvoja. Za primer razprave prvega tabora gl. npr. Mattusch (1996), dober primer razprave drugega pa je npr. Pollitt (1998).

31 Jacob Isager je na primer mnenja, da je Plinij odstopil od sheme, da se ne bi ponavljal. Večino klesarjev je namreč obravnaval že pri obravnavi obdelave brona (Isager, 1998, 149). 
Na prvi pogled se naj torej Plinijeva podoba Fidije ne bi dosti razlikovala od njegove upodobitve, kot jo vidimo na sliki Alma-Tadema. Obe temeljita na razumevanju Fidije kot Umetnika, ki ga njegov Genij jasno postavlja nad druge ljudi.

Vendar pa je ta podoba varljiva. Branje celotnega Naravoslovja, kot rečeno, jasno pokaže, da je Plinija prvenstveno zanimala Narava in možnosti njenega preoblikovanja za človekovo uporabo. ${ }^{32} \mathrm{~V}$ tem okviru postanejo razumljivejše tudi navidezne nenavadnosti, ki smo jih poudarili. V skladu s svojo sistematiko Plinij Fidije ne obravnava na več mestih zato, ker se je ta ukvarjal z različnimi likovnimi zvrstmi, ampak zato, ker je pri tem predeloval/preoblikoval različne naravne materiale. Plinij se - ne samo pri obravnavi Fidije, pač pa pri obravnavi vseh kiparskih in slikarskih del - ne ustavlja ob problemu, ali je bilo neko delo izvirnik ali zgolj njegov posnetek, ker ga posamezna skulptura ne zanima kot izvirno umetniško delo, ampak kot artefakt: kos bakrove rude spremenjen v bronasto skulpturo, kos marmorja preoblikovan $\mathrm{v}$ marmorni kip, del slonovega okla predelan $\mathrm{v}$ slonovinast kipec.

Zato je povsem razumljivo, da Plinija posamezna Fidijeva dela po pravilu ne zanimajo niti s slogovnega oz. estetskega vidika. Večino jih, tako kot pri opisih drugih likovnih del, opredeli kvečjemu z njihovim motivom. Plinija dalje ne vznemirja preveč niti dejstvo, da je Fidija svoja dela po eni strani izdeloval skupaj s svojimi učenci, po drugi strani pa jim menda celo dopustil, da jih naokrog razglašajo kot delo lastnih rok. Razlog za to se spet skriva v dejstvu, da Plinija kipi Fidije in njegovih sodelavcev ne zanimajo skozi optiko njihovega avtorstva, temveč dejansko kot fait accompli; v njih je videl končne izdelke obrtnikov, ki so obvladali svojo veščino.

Svojo veščino pa je brez dvoma obvladal tudi Plinij sam. Ta se ne kaže le v obsegu in vsebinski strukturi njegovega Naravoslovja, temveč tudi v dejstvu, ki so mu ga njegovi preučevalci sicer ponavadi očitali - dejstvu, da je pri svojem delu črpal pri drugih avtorjih. Očitek kompilatorstva je vsaj

32 Plinij s svojim navdušenjem nad človekovo zmožnostjo preoblikovanja Narave v svojem času ne pomeni kakšne posebne izjeme. Ravno nasprotno, po mnenju Johna Oniansa prav Plinij v svojem Naravoslovju najbolje ponazarja dejstvo, da je bila ideja preobrazbe ena osrednjih idej rimske kulture (Onians, 1999, 219 ss.). 
slabo premišljen, če ne celo neupravičen iz že omenjenega razloga, namreč da se njegovi avtorji niso nikoli zares posvetili vprašanju, kako in zakaj je Plinij tuje podatke vpletel v svojo pripoved. Razlog za to je tradicionalno nezanimanje za analizo Naravoslovja kot zaključene celote, ki je rabila svojemu avtorju pri doseganju njegovih ciljev.

Šele ob takem pristopu k Naravoslovju se Plinij bralcu pokaže v vlogi, ki si jo je v resnici želel igrati - vlogi artifexa. Podobno kot so Fidija in drugi obrtniki, o katerih je pisal, s svojimi veščinami v Naravi obstoječe materiale spreminjali v najrazličnejše predmete, tako je tudi Plinij obstoječe gradivo (pre)oblikoval v svojevrsten artefakt (prim. Onians, 1999, 234) - pregledno naravoslovno-enciklopedično delo v 37 knjigah. ${ }^{33}$ Najbolje o tem pričajo prav seznami uporabljenih virov, ki jih Plinij tako vestno navaja $\mathrm{v}$ prvi knjigi Naravoslovja. Sistematičnemu pregledu tem, ki jih obravnava po posameznih knjigah, avtor na koncu doda pregledno naštete avtorje del, od koder je črpal svoje podatke. ${ }^{34}$ Tako z razdelitvijo vsebine Naravoslovja na posamezne knjige kot tudi z naštevanjem svojih virov Plinij bralcu daje jasno vedeti, da gre v njegovem delu sicer res za teme, ki so jih obravnavali že drugi avtorji, vendar pa je prav on kot avtor Naravoslovja tisti, ki določa, obravnavo posameznih vsebin (vrste vsebin, vrstni red obravnave, predvsem pa povezavo posameznih vsebin $\mathrm{v}$ zaključeno in smiselno celoto).

To seveda velja tudi za njegove opise človekovih dosežkov na posameznih likovnih področjih. V Plinijevih opisih grškega slikarstva in kiparstva tako ne moremo iskati grškega razumevanja kipov in slik, ki so jih obdajali, niti ne moremo iskati rimskega pogleda na grške umetnine, ki so se na

33 V tem okviru je še posebej zanimiv odlomek uvodnega dela Naravoslovja, v katerem si Plinij zaželi, da bi bil podoben grškim kiparjem in slikarjem. Za njih namreč velja, da gledalci $\mathrm{k}$ njihovim delom pristopajo kot $\mathrm{k}$ nečemu, kar še ni dokončano (Naravoslovje, EP, 26). Iz nadaljnje pripombe, da bi lahko njegovemu delu dodali še marsikaj (Naravoslovje, EP, 28), postane še bolj jasno, da je Plinij svoje delo v resnici dojemal kot nekaj organskega, kar se vedno znova spreminja, sebe pa je videl v vlogi nekoga, ki na podlagi lastne vednosti (veščine) skrbi za obliko končnega izdelka. Za Plinija v vlogi artifexa prim. tudi Carey (2003, 180-181).

34 Da je bilo naštevanje avtorjev, od katerih je črpal, za Plinija izredno pomembno, najbolje kaže dejstvo, da je Plinij edini antični avtor, ki navaja svoje vire (Isager, 1991, 29). Namesto, da bi se raziskovalci natančneje poglobili v vprašanje, kaj je botrovalo tej Plinijevi odločitvi, pa so ga prav na podlagi obsežnih seznamov virov iz 1 . knjige Naravoslovja raje označili za kompilatorja (prim. Carey, 2003, 10; Isager, 1991, 29). 
tak ali drugačen način znašle v Rimu. Plinij bralcu v Naravoslovju podaja kvečjemu svoj lasten, politično motiviran pogled na svet, pogled, v katerem so sicer imeli pomembno vlogo tudi artefakti. Iz Plinijevih opisov grškega kiparstva lahko izvemo o grškem kiparstvu prav toliko kot iz rimskih kopij grških kipov, ki so preplavile rimsko državo - v obeh primerih gre za interpretacijo izvirnika. Stroka, še posebej pa umetnostna zgodovina se mora zato vprašati, kaj je v resnici njena naloga, ko bere Plinijevo Naravoslovje: rekonstrukcija bolj ali manj namišljenega razvoja grškega slikarstva in kiparstva ${ }^{35}$ ali odkrivanje političnih in intelektualnih možnosti, ki jih je interpretacija grške (in rimske) likovne tvornosti ponujala rimskemu izobražencu v sredini 1 . stoletja.

\section{VIRI}

Aristoteles, Poetika (slov. prevod K. Gantar). Knjižna zbirka Claritas 39, Ljubljana, 2005.

Marcus Tullius Cicero, Brutus, The Loeb Classical Library 90, Cambridge, London, 1997.

Publius Ovidius Naso, Metamorphoses, The Loeb Classical Library 42-43, Cambridge, London, 1966-1968.

Pausanias, Vodič po Heladi (srbhrv. prevod U. Pasini). Vrtlozi. Biblioteka povjesnih djela, 3, Split, 1989.

Plato, Država (slov. prevod J. Košar). Zbirka Svetovni klasiki 40, Ljubljana, 1995.

Caius Plinius Caecilius Secundus, Naturalis historia, The Loeb Classical Library 330, 352, 353, 370, 371, 392, 393, 394 in 410, Cambridge, London, 1966-1984.

35 Da je za spremembe v slikarskem in kiparskem oblikovanju od »homerskih časov« do pozne antike treba iskati vzroke $\mathrm{v}$ spremembah mentalitete in družbeno-politične stvarnosti in ne v navideznem slogovnem razvoju, predvsem pa, da te spremembe niso temeljile na uvajanju novosti oz. nekakšnem izboljševanju, je v svojem delu o klasični umetnosti pokazal J. Onians (1999). 
Marcus Fabius Quintilianus, Instituto oratoria, The Loeb Classical Library 124-127, Cambridge, London, 1976-1996.

\section{LITERATURA}

Boardman, J., Greek Art, London, 1996.

Carey, S., Pliny's Catalogue of Culture. Art and Empire in The Natural History. Oxford Studies in Ancient Culture and Representation, Oxford, 2003.

Elsner, J., Art and Roman Viewer. The Transformation of Art from the Pagan World to Christianity, Cambridge, 1995.

Isager, J., Pliny on Art and Society, Odense, 1998.

Mattusch, C., Classical Bronzes. The Art and Craft of Greek and Roman Statuary, Ithaca, London, 1996.

Onians, J., Classical Art and the Cultures of Greece and Rome, New Haven, London 1999.

Pollitt, J.J., The Art of Ancient Greece. Sources and Documents, Cambridge, 1990.

Pollitt, J.J. in drugi (ur.), Personal Styles in Greek Sculpture, Cambridge, New York, 1998.

Rubin, P. L., Giorgio Vasari. Art and History, New Haven, London, 1995.

Schneider Adams, L., The Methodologies of Art. An Introduction, Boulder, 1996.

Schweitzer, B., Xenokrates von Athen, v: Schweitzer, B.: Zur Kunst der Antike. Ausgewählte Schriften, Bd. 1, Tübingen, 1963, str. 105-164.

Spivey, N., Understanding Greek Sculpture. Ancient Meanings, Modern Readings, London, 1996.

Summers, D., Form and Gender, v: Bryson, N. in drugi, Visual Culture. Images and Interpretations, Hanover, London, 1994, str. 384-411. 
Tatarkiewicz, W., Zgodovina šestih pojmov. Umetnost - lepo - forma - ustvarjanje -prikazovanje - estetski doživljaj. Zbirka Labirinti, Ljubljana, 2000.

Trautwein, R., Geschichte der Kunstbetrachtung. Von der Norm zur Freiheit des Blicks, Köln, 1997.

Willims, R., Art Theory. An Historical Introduction, Oxford, 2004. 


\section{READING PLINY: ON PLINY THE ELDER, THE ART, AND THE METHOD}

Keywords: Pliny the Elder, Naturalis Historia, interpretation of sources, ancient art

\section{Abstract}

The Naturalis Historia by Pliny the Elder is one of the most important works of Antiquity, which influenced later understanding of Greek art and the formation of centuries of subsequent concepts, models, and methods in art history. Scholars use this work as an aid in establishing the general developmental line of Greek art production and the attribution of artifacts to individual authors. The fact that excerpts from Pliny's Naturalis Historia, especially those that describe painting and sculpture, gained the status of a reference work in studying Greek art has resulted in the discipline reading them surprisingly unambiguously.

The greatest problem in the traditional reading of Pliny's Naturalis Historia is the fact that it is usually read by individual sections that more or less correspond to the modern division of knowledge within individual academic disciplines. Although some recent studies explicitly emphasize the necessity of reading Naturalis Historia as a whole, scholars of the art of antiquity often continue to believe that the key to understanding Pliny's attitude to the artistic creativity of his own time and previous periods is hidden in the books in which the author presumably analytically describes the development of painting and sculpture.

This kind of approach to Pliny's work cannot offer a comprehensive insight into his attitude toward the art for at least two reasons. First, because of their focus on particular parts of Naturalis Historia, researchers isolate these from the context of the entire work and in reality create "new texts." Second, reading only the parts in which Pliny describes individual types of art comprises a more or less explicit idea of Pliny as an art historian; that is, an author interested in artistic production in a completely modern sense of the term. 
Only a comprehensive reading of Pliny's Naturalis Historia can lead to more suitable interpretation of the entire text and its individual parts. Analyzing the structure of individual volumes or chapters and their placement within the frame of the entire work, focusing on the use of individual words and phrases in various contexts - and, last but not least, a thorough analysis of the sources Pliny uses, with an emphasis on ideas that he borrows from these sources, and on the method he uses to incorporate them into his own narrative - enables a new understanding of Pliny as an author, as well as the goals he tried to achieve through his work.

By examining Pliny's remarks about Phidias, the author shows that in Pliny's descriptions of Greek painting and sculpture we cannot seek the Greek understanding of sculptures and paintings that surrounded the people, nor can we seek a Roman view of Greek works of art that somehow ended up in Rome. In his Naturalis Historia Pliny primarily offers the reader his own politically motivated view of the world. From Pliny's descriptions of Greek sculpture, one can find out exactly as much about Greek sculpture as from the Roman copies of Greek sculptures that flooded the Roman state: both cases deal with an interpretation of the original. Thus, in the author's opinion, the obligation of the discipline - especially art history - in reading Pliny's Naturalis Historia is not to reconstruct the more or less imaginative development of Greek painting and sculpture, but to discover the political and intellectual possibilities that the interpretation of Greek (and Roman) artistic creativity offered Roman intellectuals in the middle of the 1st century AD. 